\title{
EFFECTS OF POLITICAL MONOPOLY ON ECONOMIC DEVELOPMENT
}

\author{
WAI-MAN LiU* University of New South Wales \\ XIAOKAI YANG Monash University
}

\begin{abstract}
This paper has two objectives. First, it presents a survey of the literature surrounding the relation between political monopoly and economic development. Second, it offers an analysis of how commoners' high degree of tolerance towards unfair inequality of income distribution between theirs and the monopolizing ruling elites leads to poor economic development. We assert that free migration between states causes monopoly rent to shrink because it poses a threat to the ruling elites due to fiscal competition between states. The shrinking in monopoly rent implies a higher level of division of labour, which results in a greater extent of the market and higher aggregate productivity.
\end{abstract}

\section{POLITICAL MONOPOLY AND ECONOMIC DEVELOPMENT: A SURVEY}

One of the key driving forces of the development of capital institutions in Western Europe was the absence of a single overarching political power and intense political competition between sovereignties. The development of capital institutions has led to successful economic progress through promoting division of labour and specialization. One of the most famous observations was made by Baechler (1976), who perceptively pointed out that '[f]undamental springs of capitalist expansion are, on the one hand, the coexistence of several political units within the same cultural whole and on the other, political pluralism which frees the economy' (Baechler, 1976, p. 80). His claim received supports from many scholars and economic historians including: Hall (1988); Mokyr (1990); Jones (1981, pp. 226-35); Braudel (1984, pp. 128-9); Weber (quoted in MacFarlane, 1988, pp. 186-7); McNeill (1974); Laslett (1988, p. 235); Hoffman and Norberg (1994); and Landes (1998, p. 36). In particular, McNeill (1974) argued that:

\footnotetext{
* Address for correspondence: Wai-Man Raymond Liu, School of Banking and Finance, University of New South Wales, Sydney, NSW 2052, Australia. Email: wmr.liu@unsw.edu.au. I would like to acknowledge Yingyi Qian's discussion on a comparison between good and bad capitalism which stimulated our efforts for this paper and Paul Migrom's discussion on the monopoly power of merchant guilds in Medieval Europe. I also wish to thank James Buchanan, Ke Li, Yew-Kwang $\mathrm{Ng}$, Russell Smyth, Guang-Zhen Sun, Ian Wills, two anonymous referees and seminar participants at the University of Hong Kong, the International Symposium of Economics of e-Commerce and Networking Decisions at Monash University, the economic workshop on 'Increasing Returns and Inframarginal Economics' at Monash University and the Buchanan Workshop at Virginia Polytech and State University for helpful comments and suggestions. Part of this research was conducted while I was affiliated to the Department of Economics at Monash University. The usual disclaimer applies. The basic idea of this paper was suggested by Xiaokai Yang who passed away in July 2005 and hence could not write the paper jointly. I wrote the paper based on his idea.
} 
[t]he political pluralism of early modern Europe was,..., fundamental and distinctive. When all the rest of the civilized world reacted to the enhanced power cannon gave to a central authority by consolidating vast, imperial states, the effect in western and central Europe was to reinforce dozens of local sovereignties, each consciously competing with its neighbors both in peace and, most especially, in war. Such a political structure acted like a forced draft in a forge, fanning the flames of rival ideologies and nurturing any spark of technical innovation that promised some advantage in the competition among states. McNeill (1974, p. 125)

Landes (1998) concurred with McNeill's observation and asserted that:

Despotisms abounded in Europe, too, but they were mitigated by law, by territorial partition, and within states, by the division of power between the center (crown) and local seigneurial authority. Fragmentation gave rise to competition, and competition favoured good care of good subjects. Treat them badly, and they might go elsewhere. Ecumenical empires did not fear flight, especially when, like China, they defined themselves as the center of the universe. There was no other place to go. Landes (1998, p. 36)

In the case of China, the monopolistic nature of the imperial government in the nineteenth century and its significant involvement in commercial transactions were considered major reasons for the backwardness in economic development. Fairbank (1992) pointed out:

Oriental societies, organized under centralized monolithic governments in which the bureaucracy was dominant in almost all aspects of large-scale activity administrative, military, religious, and economic - so that no sanction for private enterprise ever became established. The merchant was kept in check by the official as an ally whose activities could be used and milked in the interest of either the officials personally or of the state. As Etienne Balazs pointed out, commercial transactions were always subject to the superintendence and taxation of the officials. Government monopolies of staple articles, like salt and iron in ancient times, or like tea, silk, tobacco, salt, and matches more recently, expressed the overriding economic prerogatives of the state. No merchant class had been allowed to rise independently and encroach upon these prerogatives. This was ensured in practice by the official disregard for private property. This meant that official patronage and support were necessary to protect any big commercial undertaking. The result was a close community of interest between the merchant and the official. ... In short, capitalism failed to prosper in China because the merchant was never able to become established outside the control of the landlord gentry and their representatives in the bureaucracy. Fairbank (1992, p. 179)

Fairbank's view was in line with empirical observations documented by other scholars, including Elvin (1973), Mokyr (1990), and Yang (2003). Mokyr (1990) claimed that the stagnation of technological innovation during the Ming and Qing eras is partly due to: (i) the lack of the imperial government's support for infrastructure and public services that are necessary for both economic development and technological progress; and (ii) the lack of competition in the Chinese political market, which caused bureaucrats to develop a strong 
tendency to preserve the status quo. Elvin (1973) argued that commercial capitalism and technology had been well developed since the Song dynasty. However, it could not develop into fully-fledged industrialization because of the political monopoly. Yang (2003, p. 2) indicated that:

[P]luralism in Europe ensured that several cultures and sovereignties could challenge each other on a nearly equal footing. In contrast, East Asian geopolitical structure ensured the hegemonism of Chinese culture prior to the invasion by Occidental cultures. No other culture could challenge it. Japanese, Mongolian, and Manchurian were conquered culturally by the Chinese, regardless of whether they subordinated to, or were rulers of, China. China is a mainland country, so it is easy to win a unification war and very expensive for inland trade. Hence, the variety of institutional experiments in East Asia was much smaller than that in Western Europe until Japan's Meiji Restoration. Yang (2003, ch. 1)

It was no accident that countries with political monopoly by ruling elites suffer long-term political instability and poor economic performance. Early empirical evidence of this phenomenon was provided by de Vires (1984) and De Long and Shleifer (1994). Using the database of cities in Western Europe from $\mathrm{AD} 1000$ to $\mathrm{AD}$ 1800, De Long and Shleifer (1994) found that regions ruled by absolutist governments without constitutional constraints had, on average, lower economic growth, lower levels of economic specialization and smaller trade networks. The evidence is strong even after controlling for regional differences. ${ }^{1}$ They also found empirical evidence that regions under the rule of constitutional monarchies or merchant oligarchies have lower tax rates. This result supports extant theories purported by North and Thomas (1973), Brennan and Buchanan (1980), North (1981) and Olson (1991), who argue that due to political competition, the primary interest of constitutional monarchies is the general economic welfare of the region rather than state revenues. A more recent paper by Acemoglu et al. (2004) examined factors contributing to the rise of Western Europe in the period between AD 1500 and $\mathrm{AD}$ 1850. They found that countries with checks and balances on their monarchies tended to have superior economic performance. This is particularly true in countries with access to the Atlantic. Countries with non-absolutist institutions prior to $\mathrm{AD} 1500$ (such as the UK and the Netherlands) experienced rapid economic development through Atlantic trade, while countries with monarchies that were highly absolutist (such as Spain and Portugal) experienced lesser gains from Atlantic trade.

A similar phenomenon is also found in Latin America, where limited political competition generates poor economic performance. Countries ruled by a monopoly state tend to have inefficiently unequal income distribution, low aggregate productivity and limited markets. ${ }^{2}$ A recent empirical study by La

\footnotetext{
${ }^{1}$ In their study, they use 'city size' as a measure of economic performance since it roughly represents the level of economic specialization, agricultural productivity and the size of the trade network.

${ }^{2}$ See also Murphy et al. (1989) and references therein, and the work of North et al. (2000) for a comparison of development experiences in North and Latin America.
} 
Porta et al. (1999) investigated the quality of government in 152 countries. They found that both the religion and the legal system of a country have implications for the emergence of political monopoly, which in turn affects the country's growth performance. First, they found that the Catholic religion has negative effects on growth performance, while the Protestantism has positive effects. Countries with Catholic religious affiliation are accustomed to a hierarchical political structure as followers are succumbed to a single political power - the Church. Its political structure has a high degree of centralization since a follower cannot set up a Catholic Church branch without the approval from Rome. Unlike the Protestant religion that has minimal religious and political control, the political ideology of Roman Catholicism had always emphasized xenophobic policies, though the situation was reversed after the mid-nineteenth century. The state and the Church in these countries tend to exert substantial resources to prevent competition. This has created conditions that have nurtured the emergence of political monopoly.

Secondly, La Porta et al. (1999) found that countries with a civil law system have, on average, poorer economic performance because law was created to enhance the power of bureaucrats, which invariably reduced government efficiency. In contrast, countries with a common law system have superior economic performance. The authors argued that the English common law system traditionally emphasizes the limiting of the power of the state and serves to protect the welfare of citizens through the more efficient enforcement of private property rights. The French civil law system, on the other hand, is more conducive to political monopoly because historically it was intended to eliminate jurisprudence and strengthen the state. Mahoney (2001) found similar evidence when comparing the economic growth of common law counties and civil law countries during the period 1960-1992. He suggested that the difference in economic performance is reflected in the greater orientation of common law towards private economic activity and the greater orientation of civil law towards government intervention.

La Porta et al.'s view, particularly on the relevance of legal heritage to economic performance, was treated with skepticism by others. ${ }^{3}$ One form of scepticism came from Dawson $(1960,1968)$ and Merryman $(1985,1996)$. They argued that colonies that adopted the French civil law system had operated it less effectively than France. Berkowitz et al. (2002) suggested that the transplant process of the legal system from the colonizer is more important than the legal heritage; whether a particular legal system is more conducive to political monopoly depends critically on the adaptability of the system in those countries. Acemoglu et al. (2001) argued that whether political monopoly is more likely to exist in countries that were once colonized by Europeans depends on the colonization policies. In colonies with inhospitable environments such as Congo, European colonizers were more likely to develop extractive institutions for exploitation than set up a secure property rights system that checked against government power. These established extractive institutions tended to

\footnotetext{
${ }^{3}$ Beck and Levine (2004) provided an excellent review of the argument.
} 
continue after independence. Thus, political monopoly is more likely to prevail in these countries.

More scepticism came from Hatzis (2005). Hatzis challenged the common perception that the civil law system is less efficient than the common law system; the latter is more flexible in adapting to the changing conditions of the social and economic environment. He contrasted the civil contract law system with the common law system and pointed that in some areas the common law system is incompatible with economic efficiency. ${ }^{4} \mathrm{He}$ argued that the efficiency of a country's legal system should not be used to explain the country's economic performance. Instead, the disparity between countries' economic performances should be attributed to cultural traditions and historical circumstances.

While it may be true that political monopoly consistently leads to poor economic performance, there are some exceptions. Countries such as Singapore, Taiwan, South Korea and Chile experienced short-run impressive growth performance under authoritarian regimes. One possible explanation, as given by Sachs et al. (2000), is that such short-run rapid growth might be achieved by latecomers to economic development through the mimicking of the industrialization pattern of a capitalist developed economy even in the absence of constitutional order. An example would be the former USSR in the 1930s. Since countries with political monopoly do not have capitalist institutional infrastructure that can foster economic development in its own capacity, such growth cannot be sustained in the long run when the room for imitation is exhausted. China can maintain impressive economic growth without suffering the same fate as the former USSR because there is still potential for imitation, despite its dual track approach of economic reform that in fact institutionalizes state opportunism and corruption. Hong Kong is a different case. Its economic performance is backed up by the legacy of the credible British constitutional order and an anti-corruption bureau.

\section{WHY DOES POLITICAL MONOPOLY PERSIST?}

Political monopoly arises when certain ideologies and belief systems such as communism, Nazism, and mercantilism ${ }^{5}$ prevail. Some elite members of the

\footnotetext{
${ }^{4}$ Hatzis contended that the common law system has a tendency to 'criminalize' the non-performing party of a contract even when breaching the contract is economically more efficient than performing it. He also argued that, in the common law system, the courts tend to ignore the penalty clauses stipulated in the contract and, instead, they award a conventional compensation to the injured party as if the contract was silent. This tendency undermines the efficient breach and renders the penalty clauses useless despite the fact that the clauses were negotiated at the time when the contract was made. ${ }^{5}$ North (1981, p. 149) referred the association of mercantilism and political monopoly to the French experience. He argued that the economic development of the Old Regime France prior to the end of 18 th century was vastly lagging behind its English rival, partly due to the rising monopoly power of local guilds granted by the French crown, who served to protect the shrinking local markets from outside competition and act as a convenient conduit of collecting fiscal revenue. To control the fiscal system, a large administrative bureaucracy was created. It was conveniently used to regulate and control the economy. Although such mercantilism also existed in Britain, its impact was trivial especially since the onset of the Industrial Revolution. The demise of guilds during this era was alongside with the escalating power of the market force (Mokyr, 1990).
} 
ruling party have charismatic personality, together with certain special characteristics of government services; they then form an elite group that effectively blocks others from entering into the political arena. These government services have certain characteristics that can easily lead to monopoly by the elite. Such services include law enforcement and defence, both of which need uniformed personnel and the sanction of legitimate police or military violence. Political monopoly may also be characterized by the government monopoly of the banking sector, foreign trade, retail and wholesale business. Stiff license systems, government approval systems for setting up firms and residential registration systems are all used to block free entry into lucrative businesses (Sachs et al., 2001). ${ }^{6}$ In pre-Glorious Revolution Britain, such blocks to free entry were characterized by many monopoly privileges held by the Crown (North, 1981; Mokyr, 1990, 1993).

If political monopoly consistently leads to poor economic performance, as revealed by ample empirical evidence, why does it persist? We provide two possible explanations below.

First, political monopoly tends to persist when citizens tolerate unfair social, economic and political inequalities. Such high levels of tolerance may be due to education, ideology, norms, moral codes and the particular religion in the society. In the absence of political competition, a high degree of tolerance generates room for the elite to squeeze monopoly rents through predatory taxes or high priced public goods. While continuing expropriation accentuates the disparities between citizens and the elite, the latter will try to keep the welfare of citizens at above the intolerance level so that the extent of inequality is not severe enough to provoke a revolution that may endanger their political position. This explains, at least partly, why countries with low per capita income generally remain in the grip of authoritarianism for a prolonged period of time (Przeworski et al.'s, 2000, ch. 2). ${ }^{7}$

The tolerance level of citizens from one state may be influenced by the behaviour of their neighbours. The rivalry between constitutional Britain and despotic France in the seventeenth and eighteenth centuries is a classic example. Prior to the French Revolution, Britain's per capita real income was 30\% higher than that of France (Mokyr, 1993, p. 45). Income distribution between the elite and commoners under the ancien régime in France was highly unequal. A substantial portion of economic production capacity was devoted to the production of luxuries for the elite. In contrast to France, in effect an absolute monarchy, the parliamentary democracy and constitutional monarchy that emerged from Britain's Glorious Revolution in 1688 provided credible commitment of the government to the constitutional order (North and Weingast,

\footnotetext{
${ }^{6}$ Another example would be the political persecution of opposition parties, such as the Chinese Democratic Party, an obvious action by the ruling party to block entry into the political arena.

${ }^{7}$ Przeworski et al. also pointed out that it is very difficult to generalize the relationship because there are exceptions in which dictatorship survived for many years in relatively wealthy and modernized countries such as Singapore, East Germany and Taiwan. Nonetheless, democracies are more likely to emerge and survive in countries that are already developed, rather than countries develop under authoritarian regimes.
} 
1989). It not only reduced the government's predatory behaviour and state opportunism but also fostered economic development. Meanwhile, a large and rising middle class in France (the bourgeoisie) observed the differences in the level of income distribution and in the levels of national wealth between the two countries. Together with the spread of Enlightenment ideals of government organization, this sector of society gradually became less tolerant towards the ancien régime. ${ }^{8}$ Escalating social unrest, led by the bourgeoisie and the peasants, eventually led to the outbreak of the French Revolution, which initiated the long process of France transforming from the ancien régime to a republic.

Secondly, political monopoly may not exist if free migration between competing states is feasible. Free migration is unfeasible if citizens face certain economical, cultural, geographical and/or political constraints. If free migration is feasible, citizens of a country with poorer economic welfare due to political monopoly will move to other countries that provide better economic welfare. This implies that free migration could pose a threat to ruling elites as it generates fiscal competition between states. The competition causes the rent of political monopoly to disappear, so that the elite class may voluntarily give up political monopoly, through an initiation of constitutional negotiation, political reconciliation and political reforms.

Let us look at the case of East Germany in the late 1980s. Despite media censorship and control within East Germany, access to West German media and the two-way visits between relatives on both sides of the border caused East Germans to realize the growing difference in their economic wellbeing compared to their neighbours. Such realization caused a downward revision of their tolerance levels towards the German Democratic Republic (GDR). When the Hungarian border opened in May 1989, a mass migration was triggered as hundreds of thousands of East German dissidents fled westwards via Hungary and Czechoslovakia. This, along with escalating protests and mass demonstrations, eventually brought down the Berlin Wall in November 1989 and catalyzed the collapse of the Soviet-style political and economic system in the socialist bloc.

This, however, has not happened in China, partly because of the large size of China's population. Mass migration of Chinese to the 'free world' is practically impossible since no country in the world could possibly absorb such levels of mass migration. This explains the lack of migration, even when per capita real incomes in Taiwan and Hong Kong are many times those in China. The political monopoly of the Chinese Communist Party, which generates both inequalities of income distribution and social injustice, can thus still survive. ${ }^{9}$

\footnotetext{
8 According to Landes (1998), many travelers including Voltaire (in exile in England, 1726-1729), found that income distribution in Britain was much more equal than under the ancien régime in France. Hence, " "The English", wrote Charles marquis de Biencourt, "have the wit to make things for the people, rather than for the rich", which gave them a large and steady custom' (Landes, 1998, p. 222).

${ }^{9}$ Such inefficient inequality of income distribution in China is reported in Sachs et al. (2001). The Gini coefficient, which ignores hidden illegal income such as free high quality houses and cars provided to ruling elites, was as high as 0.45 in China in the 1990s.
} 
Let us look at how free migration affects economic development. Assume that there are two countries with similar sizes. Individuals are allowed to freely migrate between them. Suppose, one of them is ruled by a political monopoly and the other is ruled by a constitutional monarch with restricted powers. In both countries, citizens must consume public goods to facilitate trades. The costs of public goods are paid in the form of tax subsidies. Examples of these public goods include the administration of infrastructure, judicial services, law enforcement, transportation services and transaction services. These goods are provided by the state because their production primarily involves large fixed costs but negligible variable costs and they are non-excludable (like national defence, itself intrinsically impossible to price) or excludable with prohibitively high costs of enforcing the property rights pertaining to public goods. ${ }^{10}$

Citizens must face the trade-off between the economies of division of labour and the costs of public goods. In a country ruled by a political monopoly, the costs of public goods are prohibitively high due to expropriation by the elite. Such high costs of public goods may outweigh the economic benefits obtained from division of labour. That is, citizens choose autarky because they are discouraged from trades as the latter incur the high costs of public goods. This not only generates unequal income distribution (between commoners and the elite), the equilibrium level of division of labour is lower in the country with political monopoly than in a country with a constitutional monarch. As shown in Yang (1996; 2001, pp. 270-274), a lower division of labour implies an individual's lower level of specialization and the smaller extent of the market. This also implies a lesser degree of commercialization, trade dependence, market integration, production concentration, the extent of endogenous comparative advantage, the diversity of occupations and economic structure and a greater degree of self-sufficiency. Because of economies of division of labour, the equilibrium level of aggregate productivity under the regime of political monopoly is lower than the Pareto optimum. Yang (2003) considered such state opportunism as a major detriment to economic development.

Free migration implies that citizens in the country with political monopoly will move to other countries with better economic development. The elite is thus under pressure to reduce the monopoly rent if states are competing for tax revenues. A further shrinking in the monopoly rent causes the elite to give up its political monopoly, which implies an initiation of constitutional negotiation, political reconciliation and political reform. ${ }^{11}$ This process not only abolishes the political monopoly of the elite, but also reduces the inefficient inequality of income distribution, enlarges the extent of the market and raises the level of division of labour and degrees of diversity of occupations, commercialization, market integration and trade dependence.

\footnotetext{
${ }^{10}$ This line of argument follows from Coase's (1960) seminal analysis and is further discussed in Cheung (1970).

${ }^{11} \mathrm{Li}$ and Smyth (2004) showed how fiscal competition between sovereigns results in a more efficient institutional arrangement through supporting a higher level of division of labour, raises aggregate productivity and reduces income inequality between sovereign and subjects.
} 


\section{CONCLUSION}

This paper serves two purposes. First, it surveys the existing literature of the effect of political monopoly on economic development. Secondly, it analyzes how free migration between nations with different political structures promotes economic development. While political monopoly by the ruling elite generates high priced public goods and unfair income inequality, resulting in a narrow market, limiting the social division of labour and lowers aggregate productivity, free migration reduces an individual's tolerance of unfair inequality in the country with political monopoly. Fiscal rivalry between states will crowd out the one that provides inferior economic welfare.

As is well known, however, historians and scholars of other disciplines agree to disagree about the driving mechanisms of political and economic development. We acknowledge that the analysis presented in this paper is rather sketchy as it ignores many other complicated cultural, political and economic factors. We are cautious about the applicability of the theory for predicting what is going to happen to China and other countries with political monopoly since it does not seek to explain why some authoritarian regimes grow rapidly, for example, Singapore, Taiwan, South Korea and Chile. But our theory helps to explain the economic disparity between constitutional Britain and despotic France prior to the French Revolution, and how the monopolistic nature of the state severely limits economic development in China, Europe and the Latin America. We believe that our analysis may help to resolve some long-standing puzzles and already hotly debated issues in the study of economic history.

\section{REFERENCES}

Acemoglu, D., S. Johnson and J. A. Robinson (2001) 'The Colonial Origins of Comparative Development: An Empirical Investigation', American Economic Review 91, 1369-401.

Acemoglu, D., S. Johnson and J. A. Robinson (2004) 'The Rise of Europe: Atlantic Trade, Institutional Change and Economic Growth', Working Paper, Department of Economics, MIT.

Baechler, J. (1976) The Origins of Capitalism, translated by Barr Cooper. Oxford: Blackwell.

Beck, T. and R. Levine (2004) 'Legal Institutions and Financial Development', Handbook of New Institutional Economics. The Netherlands: Kluwer Dordrecht.

Berkowitz, D., K. Pistor, K. and J. F. Richard (2002) 'Economic Development, Legality, and the Transplant Effect', European Economic Review 47, 165-95.

Braudel, F. (1984) Civilization and Capitalism, 18th Century, translation from French, revised by Sian Reynolds. London: Collins.

Brennan, H. G. and J. M. Buchanan (1980) The Power to Tax: Analytic Foundations of a Fiscal Constitution. Cambridge: Cambridge University Press.

Cheung, S. N. S. (1970) 'The Structure of a Contract and the Theory of a Non-Exclusive Resource', Journal of Law and Economics 13, 49-70.

Coase, R. H. (1960) 'The Problem of Social Cost', Journal of Law and Economics 3, 1-44.

Dawson, J. P. (1960) A History of Lay Judges. Harvard University Press, Cambridge, MA.

Dawson, J. P. (1968) The Oracles of the Law. Ann Arbor: University of Michigan Law School.

De Long, B. J. and A. Shleifer (1994) 'Princes and Merchants: European City Growth Before the Industrial Revolution', Journal of Law and Economics 36, 671-702.

Elvin, M. (1973) The Pattern of the Chinese Past. London: Eyre Methuen.

Fairbank, J. K. (1992) China: A New History. Cambridge, MA: Belknap Press of Harvard University Press.

Hall, J. A. (1988) 'State and Societies: the Miracle in Comparative Perspective', in J. Baechler, J. A. Hall and M. Mann (eds), Europe and the Rise of Capitalism. Cambridge: Blackwell. 
Hatzis, A. (2005) 'Civil Contract Law and Economic Reasoning - an Unlikely Pair?', Working Paper, University of Athens.

Hoffman, P. and K. Norberg (eds) (1994) Fiscal Crises, Liberty, and Representative Government 1450-789. Stanford, CA: Stanford University Press.

Jones, E. L. (1981) The European Miracle: Environments, Economies and Geopolitics in the History of Europe and Asia. Cambridge: Cambridge University Press.

La Porta, R., F. Lopez-de-Silanes, A. Shleifer and R. Vishny (1999) 'The Quality of Government', Journal of Law, Economics and Organization 15, 222-79.

Landes, D. S. (1998) The Wealth and Poverty of Nations. New York: W. W. Norton.

Laslett, P. (1988) 'The European Family and Early Industrialization', J. Baechler, J. A. Hall and M. Mann (eds), Europe and the Rise of Capitalism. Cambridge: Blackwell.

Li, K. and R. Smyth (2004) 'Divisions of Labour, Specialization and the Enforcement of a System of Property Rights: a General Equilibrium Analysis', Pacific Economic Review 9, 307-26.

MacFarlane, A. (1988) 'The Cradle of Capitalism: The Case of England', in J. Baechler, J. A. Hall and M. Mann (eds), Europe and the Rise of Capitalism. Cambridge: Blackwell.

Mahoney, P. G. (2001) 'The Common Law and Economic Growth: Hayek Might Be Right', Journal of Legal Studies 30, 503-25.

McNeill, W. H. (1974) The Shape of European History. Oxford: Oxford University Press.

Merryman, J. H. (1985) The Civil Law Tradition: an Introduction to the Legal Systems of Western Europe and Latin America. Stanford, CA: Stanford University Press.

Merryman, J. H. (1996) 'The French Deviation', American Journal of Comparative Law 44, 10919.

Mokyr, J. (1990) The Lever of Riches: Technological Creativity and Economic Progress. New York: Oxford University Press.

Mokyr, J. (1993) 'The New Economic History and the Industrial Revolution', in J. Mokyr (ed.), The British Industrial Revolution: an Economic Perspective. Boulder and Oxford: Westview Press.

Murphy, K., A. Schleifer and R. Vishny (1989) 'Income Distribution, Market Size, and Industrialization', Quarterly Journal of Economics 104, 537-64.

North, D. C. (1981) Structure and Change in Economic History. New York: Norton.

North, D. C., W. Summerhill and B. Weingast (2000) 'Order, Disorder, and Economic Change: Latin America vs. North America', in B. Bueno de Mesquita and H. Root (eds), Governing for Prosperity. New Haven: Yale University Press.

North, D. C. and R. P. Thomas (1973) The Rise of the Western World: a New Economic History. Cambridge: Cambridge University Press.

North, D. C. and B. Weingast (1989) 'Constitutions and Commitment: The Evolution of Institutions Governing Public Choice in Seventeenth-Century England', Journal of Economic History 49, 803-32.

Olson, M. (1991) 'Autocracy, Democracy and Prosperity', in R. Zeckhauser (ed.), Strategy and Choice. New York: MIT Press.

Przeworski, A., M. E. Alvarez, J. A. Cheibub and F. Limongi (2000) Democracy and Development. Cambridge: Cambridge University Press.

Sachs, J., T. W. Woo and X. Yang (2000) 'Economic Reforms and Constitutional Transition', Annals of Economics and Finance 1, 260-74.

de Vires, J. (1984) European Urbanization, 1500-1800. Cambridge: Cambridge University Press.

Yang, X. (1996) 'A New Theory of Demand and the Emergence of International Trade from Domestic Trade', Pacific Economic Review 1, 215-7.

Yang, X. (2001) Economics: New Classical Versus Neoclassical Frameworks. Cambridge, MA: Blackwell.

Yang, X. (2003) Development Economics: Inframarginal Versus Marginal Analyses. Cambridge, MA: Blackwell. 